\title{
SMR
}

\section{Study of genetic variation of eggplant cultivars by using RAPD-PCR molecular markers and the relationship with Phomopsis blight disease reaction}

\author{
H.A. Asad ${ }^{1}$, M.B. Meah ${ }^{1}$, S.N. Begum ${ }^{2}$, M.I. Khalil' ${ }^{2}$ M.Y. Rafii ${ }^{3,4}$ and M.A. Latif ${ }^{4,5}$ \\ 1'Department of Plant Pathology, Bangladesh Agricultural University, \\ Mymensingh, Bangladesh \\ 2Bangladesh Institute of Nuclear Agriculture, Mymensingh, Bangladesh \\ ${ }^{3}$ Institute of Tropical Agriculture, Universiti Putra Malaysia, Serdang, \\ Selangor, Malaysia \\ ${ }^{4}$ Department of Crop Science, Faculty of Agriculture, Universiti Putra Malaysia, \\ Serdang, Selangor, Malaysia \\ ${ }^{5}$ Plant Pathology Division, Bangladesh Rice Research Institute, Gazipur, Bangladesh \\ Corresponding author: M.A. Latif \\ E-mail: alatif1965@yahoo.com
}

Genet. Mol. Res. 14 (4): 17007-17018 (2015)

Received August 5, 2015

Accepted October 6, 2015

Published December 16, 2015

DOI http://dx.doi.org/10.4238/2015.December.16.1

\begin{abstract}
Disease susceptibility and genetic variability in 10 eggplant genotypes were studied after inoculating Phomopsis vexans under confined field conditions. Random amplified polymorphic DNA (RAPD) markers were used to assess genetic variation and relationships among eggplant genotypes. The disease index of leaves ranged $0.208-13.79 \%$, while fruit infection ranged $2.15-42.76 \%$. Two varieties, Dohazari G and Laffa S, were found to be susceptible, 6 were moderately resistant, 1 was moderately susceptible, and BAU Begun-1 was resistant to $P$. vexans. Amplification of genomic DNA by using 3 RAPD primers produced 20 bands: 14 (70\%) were polymorphic and $6(30 \%)$ were monomorphic. The highest intra-
\end{abstract}


variety similarity indices values were found in ISD 006, Ishurdi L, Jessore $\mathrm{L}$, and BAU Begun-1 (100\%), while the lowest was in Dohazari G (90\%). The lowest genetic distance (0.0513) and the highest genetic identity (0.9500) were observed between the ISD 006 and Ishurdi $L$ combinations. A comparatively higher genetic distance (0.3724) and the lowest genetic identity (0.6891) were observed between the ISD 006 and Dohazari $G$ combinations. A dendogram was constructed based on Nei's genetic distance, which produced 2 main clusters of the genotypes - Cluster I: ISD 006, Ishurdi L, Marich begun L, BAU Begun-1, Marich begun S, and Chega and Cluster 2: Laffa S, Dohazari G, Jessore L, and Singhnath. Genetic variation and its relationship with disease susceptibility were assessed using RAPD markers, to develop disease-resistant varieties and improve eggplant crops.

Key words: Eggplant; Genetic variation; Phomopsis blight; Resistance; Random amplified polymorphic DNA

\section{INTRODUCTION}

Eggplant or brinjal (Solanum melongena) is an important vegetable and is extensively grown in many countries of the world, with a total production of approximately 32 million tons (Choudhary and Gaur, 2009). It is cultivated and available year-round in Bangladesh, with annual production reaching $341,000 \mathrm{t}$ in the year 2009-2010 (BBS, 2011). Phomopsis blight caused by Phomopsis vexans is a major limitation to successful cultivation of eggplant in Bangladesh (Das, 1998). The disease has been reported to cause $15-20 \%$ yield loss (30-50\% in severe cases) (Das, 1998). The loss is estimated to be US\$ 134 million per year resulting from Phomopsis blight and fruit rot of eggplant in Bangladesh (Meah et al., 2002). The pathogen is seed-borne and can survive in the soil for long periods of time (Kalda et al., 1977).

Eggplant shows high diversity because there are many varieties, cultivars, landraces, hybrids, advanced lines, and wild races in the Asiatic region. More than 60 eggplant cultivars are grown in Bangladesh (Meah et al., 2007); a wide range of genetic variability exists among cultivated varieties. Genetic information regarding disease susceptibility and characteristics that contribute to yield must be examined to improve eggplant crop production. For rapid and efficient plant breeding programs, knowledge of the interrelationships among disease susceptibility and factors affecting yield are necessary.

The qualitative and quantitative improvement of crops depends on the available gene pool and its manipulation. Genetic diversity studies based on morphological traits and molecular marker studies enable the evaluation of genetic variation prior to the initiation of a new breeding program. The random amplified polymorphic DNA (RAPD) technique is a widely used, easy, and inexpensive. In this method, DNA fragments are amplified by polymerase chain reaction (PCR) using primers with arbitrary sequences for rapid screening of polymorphisms. An advantage of this method is that no prior knowledge of the sequence is required (Sobral and Honeycutt, 1993). Because primers can be chosen arbitrarily, any organism can be mapped with the same set of primers, but some loss of information occurs because RAPD markers are dominant. Though RAPD has some limitations, it has been used extensively for genetic studies, such as for analyzing genetic variation in plants 
and microbes (Demir et al., 2010; Ali et al., 2011; Aruga et al., 2012; Joshi et al., 2013; Izadiyan and Taghavi, 2013) and constructing linkage maps for certain plant species (Yang and Quiros, 1995). RAPD methods have been successfully used to examine genetic variability in eggplant in different countries (Karihaloo and Gottlieb, 1995; Singh et al., 2006; Yasmin et al., 2006; Demir et al., 2010; Ali et al., 2011; Sharmin et al., 2011; Laila et al., 2012; Khalil et al., 2013). However, the relationship between genetic variation and susceptibility to Phomopsis blight has not been examined. Therefore, the present study was conducted to evaluate the molecular variability and relatedness of 10 eggplant varieties and their susceptibility to Phomopsis blight disease using RAPD-PCR.

\section{MATERIAL AND METHODS}

\section{Evaluation of eggplant genotypes for resistance to phomopsis blight}

\section{Plant materials and experimentation}

Seeds of 10 eggplant cultivars, ISD-006, Laffa S, Dohazari G, Jessore L, Singhnath, Marich begun S, Marich begun L, BAU Begun-1, Ishurdi L, and Chega, were obtained from the IPM Lab, Department of Plant Pathology, Bangladesh Agricultural University, Mymensingh, Bangladesh.

The experiment was conducted in the field laboratory of the Department of Plant Pathology, Bangladesh Agricultural University, Mymensingh. The experiment was laid out in a randomized complete block design with 3 replications. The unit plot size was $4.0 \times 2.5 \mathrm{~m}$, maintaining a row-torow distance $60 \mathrm{~cm}$ and plant-to-pant distance of $50 \mathrm{~cm}$. Fertilizers were applied at recommended doses (Anonymous, 2005). Irrigation and intercultural operations were conducted when necessary.

\section{Inoculation of eggplant with Phomopsis vexans}

A virulent isolate of Phomopsis vexans was used for inoculation. The cultures were collected from the IPM lab and multiplied in potato dextrose agar medium. In each plot, inoculation of 5 plants was conducted during the pre-flowering stage and 5 plants during the fruiting stage. A $70-\mathrm{mL}$ spore suspension $\left(5 \times 10^{6} \mathrm{spores} / \mathrm{mL}\right)$ was sprayed onto each plant (Islam, 2006). Spraying was done at afternoon, and inoculated plants were covered with a moist transparent polythene bag for $48 \mathrm{~h}$ to ensure better infection (Islam, 2006).

\section{Assessment of Phomopsis blight and fruit rot}

After inoculation, symptoms on leaves, flowers, and fruits were observed at 7-day intervals for up to 21 days. Data regarding leaf infection (\%), percent leaf area diseased (LAD), flower infection (\%), fruit infection (\%), and percent fruit area diseased (FAD) were recorded. Disease severity was recorded according to the standard rating scale (1-5) (Islam et al., 1990). The percent disease index (PDI) was calculated according to the formula described by Singh (1984).

\section{Harvesting and data recording}

Characteristics affecting eggplant yield were examined and data were recorded for all plants. Plant height, number of primary branches per plant, number of secondary branches per 
plant, number of fruits per plant, fruit length, fruit breadth, and individual fruit weight were recorded in the field. Mature fruits were harvested at the edible stage at an interval of 7 days. Five fruits per variety were allowed to ripen and the seeds were collected to grow plants in the following year.

\section{Data analysis}

Data were analyzed to determine statistical significance. Analysis of variance followed by Duncan's multiple range test (DMRT) to test the differences between the genotypes using the computer based software MSTATC.

\section{Molecular characterization of eggplant cultivars using RAPD markers}

\section{Genomic DNA extraction and quantification}

The seeds of 10 selected eggplant cultivars were used for the RAPD analysis. To obtain genomic DNA, the youngest healthy leaf samples collected from 15-day-old seedlings were used. A modified cetrimonium bromide mini-prep method was followed to extract DNA from leaf samples (Kabir, 2007). The concentrations of DNA in the samples were determined using a UV spectrophotometer at $260 \mathrm{~nm}$. DNA quality was verified by electrophoreses on a $0.8 \%$ agarose gel in Tris-boric acid-EDTA buffer.

\section{PCR amplification and electrophoresis}

RAPD amplification reactions were conducted following the procedure described by William et al. (1990) with some modifications. Screening was conducted with 14 arbitrary decamer primers (Bangalore Genei, India). Three primers (OPA17, OPB07, OPE8) showing scorable and good reproducible bands were selected for subsequent RAPD analysis of eggplant germplasms.

PCR reactions were performed on each DNA sample in a $10-\mu \mathrm{L}$ reaction mixture containing 1X PCR buffer (10 mM Tris $\mathrm{HCl} \mathrm{pH} \mathrm{8.5,50} \mathrm{mM} \mathrm{KCl,} \mathrm{and} 15 \mathrm{mM} \mathrm{MgCl}_{2}$ ), $10 \mathrm{mM}$ of each dNTP, 5 pmol primer, 2 U Taq DNA polymerase (Bengalore Genei, India), 100 ng genomic DNA, and the remaining volume in sterile deionized water. DNA amplification was carried out in a DNA thermocycler (Biometra, Röttingen, Germany) with the following thermal profile: initial denaturation for $3 \mathrm{~min}$ at $94^{\circ} \mathrm{C}$ followed by 41 cycles of $1 \mathrm{~min}$ denaturation at $94^{\circ} \mathrm{C}, 1 \mathrm{~min}$ annealing at $35^{\circ} \mathrm{C}$, and extension at $72^{\circ} \mathrm{C}$ for $2 \mathrm{~min}$. A final extension step at $72^{\circ} \mathrm{C}$ for $7 \mathrm{~min}$ was conducted for complete extension of all amplified fragments. The PCR products were stored at $4^{\circ} \mathrm{C}$ until electrophoresis. Reaction mixtures were mixed with $2.0 \mu \mathrm{L} 6 \mathrm{X}$ loading dye. Amplified fragments were separated on a $1.5 \%$ agarose gel (Bangalore Genei, India) in 0.5X Tris-boric acid-EDTA buffer along with 20 bp DNA weight marker (Bengalore Genei, Bangalore, India) for $2 \mathrm{~h}$ at $100 \mathrm{~V}$. The gel was stained with $0.1 \mu \mathrm{g} / \mathrm{mL}$ ethidium bromide solution for $15 \mathrm{~min}$. Fragments were visualized under a UVtransilluminator and photographed using the Gel Documentation System (Biometra).

\section{Scoring and data analysis}

Each band was considered to represent a phenotype at a single locus because all RAPD markers were dominant (Williams et al., 1990). The amplified bands were visually scored as present 
(1) and absent (0) for each individual and each primer. The scores obtained were pooled to create a single data matrix. This was used to estimate polymorphic loci, Nei's genetic distance (1973), genetic diversity, genetic distance (D), and the unweighted pair group method with arithmetic mean dendrogram using the computer program, POPGENE (Version 1.31) (Yeh et al., 1999). The same program was used to test for homogeneity in different loci between population pairs.

\section{RESULTS AND DISCUSSION}

\section{Evaluation of eggplant genotypes against $P$. vexans}

The inoculated eggplant genotypes showed different percentages of leaf infection and severity (leaf area diseased) (Table 1). Among the eggplant genotypes, the highest leaf infection $(30.64 \%)$ was observed in cultivar Dohazari G followed by Laffa S (15.21\%). BAU Begun-1 showed the lowest (1.36\%) leaf infection and was statistically identical to Chega. The highest PDI in leaves was recorded in the cultivar Dohazari G $(13.79 \%)$, followed by the cultivar Laffa S $(6.14 \%)$. The lowest PDI was calculated for BAU Begun-1. Based on the PDI values, the cultivar BAU Begun-1 was graded as resistant, while cultivar ISD-006, Jessore L, Marich begun S, Marich begun L, Ishurdi L, and Chega were graded as moderately resistant. Singhnath was moderately susceptible and Dohazari G and Laffa S were susceptible (Table 1).

\begin{tabular}{|c|c|c|c|}
\hline Genotypes & Leaf infection (\%) & PDI (leaf) & Reaction \\
\hline ISD-006 & $9.98^{\mathrm{cd}}$ & $3.97^{\circ}$ & MR \\
\hline Laffa S & $15.21^{\mathrm{b}}$ & $6.14^{b}$ & MR \\
\hline Dohazari G & $30.64^{a}$ & $13.79^{\mathrm{a}}$ & $S$ \\
\hline Jessore & $7.18^{d}$ & $2.97^{\mathrm{cd}}$ & MR \\
\hline Singhnath & $12.61^{\mathrm{bc}}$ & $5.86^{b}$ & MS \\
\hline Marich Begun S & $10.10^{\text {cd }}$ & $3.84^{c}$ & MR \\
\hline Marich Begun L & $13.28^{\mathrm{bc}}$ & $4.05^{\circ}$ & MR \\
\hline BAU Begun-1 & $1.36^{e}$ & $0.21^{\mathrm{e}}$ & $\mathrm{R}$ \\
\hline Ishurdi L & $7.93^{\mathrm{d}}$ & $3.20^{\mathrm{cd}}$ & MR \\
\hline Chega & $2.50^{\mathrm{e}}$ & $1.34^{\mathrm{de}}$ & MR \\
\hline
\end{tabular}

Column having common letter(s) do not differ significantly at $5 \%$ level of probability. $\mathrm{R}=$ resistant; $\mathrm{MR}=$ moderately resistant; $\mathrm{S}=$ susceptible; $\mathrm{HS}$ = highly susceptible.

Upon inoculation, fruits of different eggplant genotypes showed different lesion sizes and percentage of fruit infection (Table 2). Among the eggplants genotypes, the highest lesion size was observed in cultivar Dohazari G $\left(3.367 \mathrm{~cm}^{2}\right)$ followed by cultivar Laffa $\mathrm{S}\left(2.223 \mathrm{~cm}^{2}\right)$; other cultivar lesions were less than $1 \mathrm{~cm}^{2}$. Among the genotypes, BAU Begun-1 showed the smallest lesion, which was statistically similar to the genotypes Jessore L, Ishurdi L, and Chega.

Fruit infection ranged from 2.15 to $42.76 \%$. The highest percentage of fruit infection was recorded in genotype/cultivar Dohazari G followed by Laffa S (Table 2). The lowest percentage of fruit infection was recorded in genotype BAU Begun-1. The highest PDI on fruit was recorded in the genotype of Dohazari G followed by Laffa S. The lowest PDI on fruit was found in genotype BAU Begun-1. Based on the PDI values on fruit, the genotype BAU Begun-1 was graded as resistant whereas cultivar ISD-006, Jessore L, Ishurdi L, Marich begun S, Marich begun L, and Chega graded were moderately resistant, Singhnath was moderately susceptible, and Dohazari $G$ and Laffa $S$ were susceptible (Table 2). 
Table 2. Lesion size and infection produced on fruits of 10 eggplant genotypes inoculated with Phomopsis vexans.

\begin{tabular}{|c|c|c|c|c|}
\hline Genotypes & Lesion size $(\mathrm{cm} 2)$ & Fruit infection (\%) & PDI (fruit) & Reaction \\
\hline ISD-006 & $0.895^{\text {cd }}$ & $11.88^{\mathrm{ef}}$ & $7.18^{c}$ & MR \\
\hline Laffa S & $2.223^{b}$ & $36.40^{\mathrm{b}}$ & $28.46^{\mathrm{a}}$ & $S$ \\
\hline Dohazari G & $3.367^{\mathrm{a}}$ & $42.76^{a}$ & $28.53^{\mathrm{a}}$ & $S$ \\
\hline Jessore L & $0.287^{d}$ & $24.03^{\mathrm{cd}}$ & $8.20^{c}$ & MR \\
\hline Singhnath & $1.667^{b c}$ & $28.43^{\mathrm{c}}$ & $14.61^{b}$ & MS \\
\hline Marich Begun S & $0.839^{\text {cd }}$ & $22.53^{\text {cd }}$ & $7.73^{c}$ & MR \\
\hline Marich Begun L & $0.773^{\text {cd }}$ & $31.17^{\mathrm{cd}}$ & $7.84^{c}$ & MR \\
\hline BAU Begun-1 & $0.039^{d}$ & $2.15^{f}$ & $0.49^{d}$ & $\mathrm{R}$ \\
\hline Ishurdi L & $0.336^{d}$ & $18.89^{e}$ & $6.14^{c}$ & MR \\
\hline Chega & $0.446^{d}$ & $5.44^{f}$ & $2.75^{d}$ & MR \\
\hline
\end{tabular}

Column having common letter(s) do not differ significantly at the $5 \%$ level of probability. $\mathrm{R}=\mathrm{resistant}$; MR = moderately resistant; $\mathrm{MS}$ = moderately susceptible; $\mathrm{S}=$ susceptible.

Evaluation of the 10 eggplant genotypes revealed that BAU Begun-1 was resistant and Dohazari $G$ was susceptible against $P$. vexans. The genotype BAU Begun-1 is only the variety that was resistant to $P$. vexans in Bangladesh according to Islam (2006), Meah and Islam (2005), Meah (2003), and Meah et al. (1998). Some genotypes were moderately resistant, while some were moderately susceptible to $P$. vexans. Similar results were observed by Islam (2006) in Bangladesh. Meah (2003) found that BAU Begun-1 and Katabegun (wild) were resistant to P. vexans. Similar studies in India revealed the existence of differential response among eggplant varieties to infection by P. vexans in an inoculation test (Kalda et al., 1977; Quaiser and Ahmad, 1987; Khodke, 1990).

\section{Molecular characterization of eggplant cultivars using RAPD markers}

The number of fragments amplified per primer varied. Three primers generated 20 bands ranging in size from 100 to 1500 base pairs (Figures 1,2, and 3). Of the 20 distinct bands, 14 bands $(70.00 \%)$ were considered to be polymorphic and 6 bands (30.00\%) were monomorphic among the 10 eggplant varieties/genotypes.

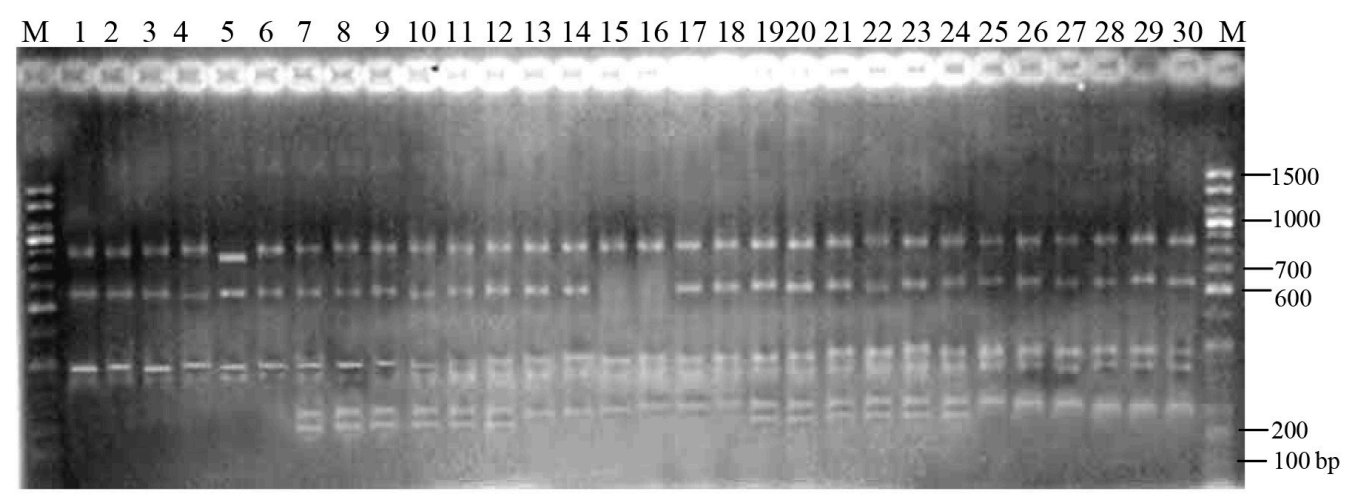

Figure 1. RAPD profiles of 10 eggplant varieties using primer OPA17. Lanes 1-3 = ISD 006; lanes 4-6 = Laffa S; lanes 7-9 = Dohazari G; lanes 10-12 = Jessore L; lanes 13-15 = Singhnath; lanes 16-18 = Marich begun S; lanes 19-21 = Marich begun L; lanes 22-24 = BAU Begun-1; lanes 25-27 = Ishurdi L; lanes 28-30 = Chega. Lane M = molecular weight marker (20-base pair DNA ladder). 


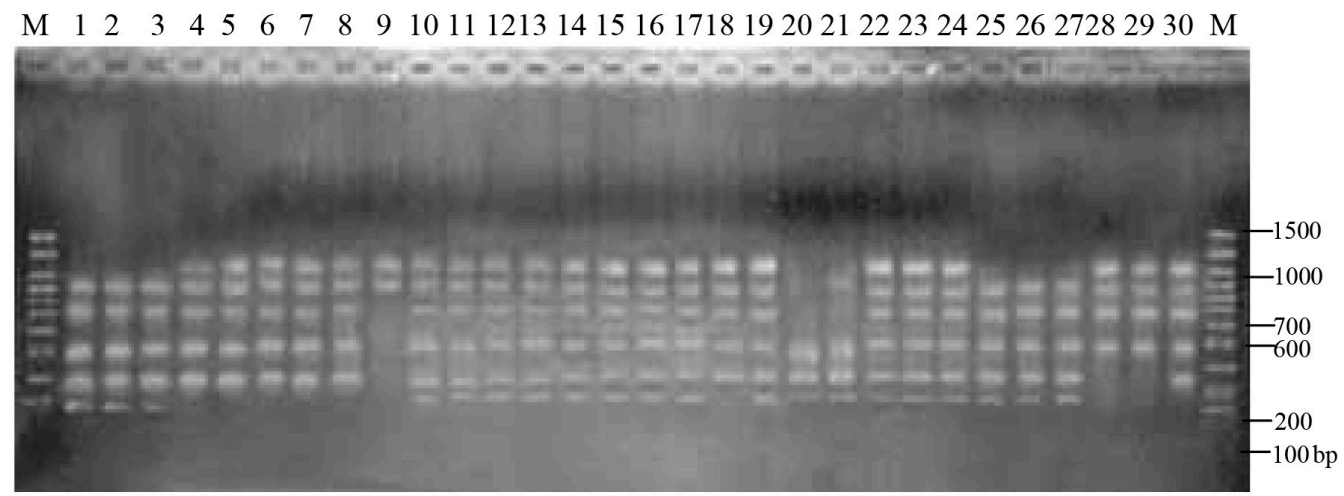

Figure 2. RAPD profiles of 10 eggplant varieties using primer OPB07. Lanes 1-3 = ISD 006; lanes 4-6 = Laffa S; lanes 7-9 = Dohazari G; lanes 10-12 = Jessore L; lanes 13-15 = Singhnath; lanes 16-18 = Marich begun S; lanes 19-21 = Marich begun L; lanes 22-24 = BAU Begun-1; lanes 25-27 = Ishurdi L; lanes 28-30 = Chega. Lane M = molecular weight marker (20-base pair DNA ladder).

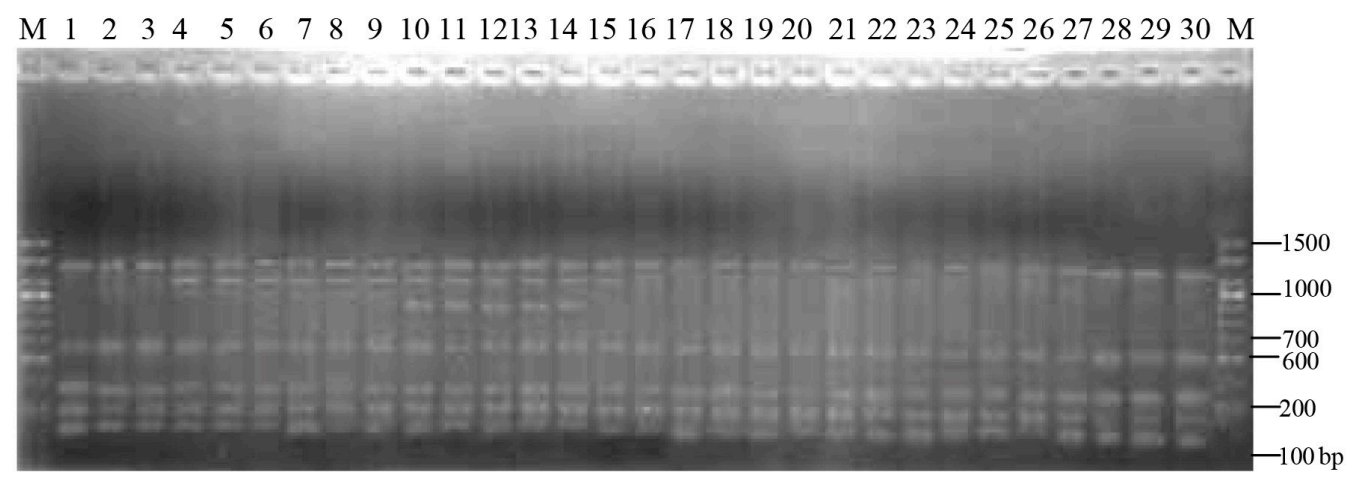

Figure 3. RAPD profiles of 10 eggplant varieties using primer OPE8. Lanes 1-3 = ISD 006; lanes 4-6 = Laffa S; lanes 7-9 = Dohazari G; lanes 10-12 = Jessore L; lanes 13-15 = Singhnath; lanes 16-18 = Marich begun S; lanes 19-21 = Marich begun L; lanes 22-24 = BAU Begun-1; lanes 25-27 = Ishurdi L; lanes 28-30 = Chega. Lane M = molecular weight marker (20-base pair DNA ladder).

Among the 3 primers, OPB07 produced the largest number of polymorphic bands (6), indicating a high level of polymorphism, whereas the primers OPA17 and OPE 8 produced 5 and 3 polymorphic bands, respectively (Table 3).

Table 3. RAPD primers with corresponding bands scored and their size range together with polymorphic bands observed in 10 eggplant cultivars.

\begin{tabular}{llccc}
\hline Primer codes & Sequences $\left(5^{\prime}-3^{\prime}\right)$ & Number of bands & Number of polymorphic bands & Polymorphic loci (\%) \\
\hline OPA17 & GACCGCTTGT & 7 & 5 & 70.00 \\
OPB07 & GGTGACGCAG & 6 & 6 & \\
OPE8 & TCACCACGGT & 7 & 3 & \\
Total & & 20 & 14 & \\
Average & & 6.67 & 4.66 & \\
\hline
\end{tabular}


The primer OPA17 and OPE8 produced the largest number of bands (7), whereas OPB07 generated 6 bands. In contrast, the primer OPB07 amplified the largest number of polymorphic bands (6). The average number of bands and polymorphic bands produced by the 3 primers were 6.67 and 4.66 , respectively (Table 3 ). The percentage of polymorphic loci was $70.00 \%$.

The number of bands per primer varied from 6-7, with a mean value of 6.66. The average number of polymorphic bands was 4.66. A similar number of polymorphic RAPD bands per primer with a mean (5.9) was reported by Karihaloo and Gottlieb (1995) in eggplant varieties and in related weedy forms known as insanum (5.7). A similar polymorphism level expressed by arbitrary primers was obtained in other RAPD studies, such as in maize (Valdmar et al., 2004) and eggplant (Chakraborty, 2006; Kabir, 2007; Demir et al., 2010; Sharmin et al., 2011; Khalil et al., 2013).

\section{Intra- and inter-variety similarity indices}

The highest intra-variety similarity index $\left(\mathrm{S}_{\mathrm{i}}\right)$ values were found in the ISD 006, Jessore L, BAU Begun-1, and Ishurdi L varieties (100\%), followed by Marich begun S, Chega, Singhnath, Laffa $\mathrm{S}$, Marich begun $\mathrm{L}$, and Dohazari $\mathrm{G}$. The lowest intra-variety similarity index $\left(\mathrm{S}_{\mathrm{i}}\right)$ value of $90.47 \%$ was found in Dohazari G (Table 4). Eggplants genotypes showing higher intra-variety similarity and a lower frequency of polymorphic loci are likely to show less heterozygosity compared to those showing lower intra-variety similarity. Varieties with lower similarity are less homogenous.

Table 4. Summary of band sharing based percentage similarity indices within individuals of 10 eggplant genotypes.

\begin{tabular}{lcccc}
\hline Varieties & \multicolumn{2}{c}{ Similarity $(\%)$} & Mean $\left(\mathrm{S}_{\mathrm{i}}\right)$ \\
\cline { 2 - 4 } & OPA17 & OPB07 & OPE8 \\
\hline ISD 006 & 100.0 & 100.0 & 100.0 & 100.0 \\
Laffa S & 83.33 & 100.0 & 100.0 & 94.44 \\
Dohazari G & 100.0 & 71.41 & 100.0 & 90.47 \\
Jessore L & 100.0 & 100.0 & 100.0 & 100.0 \\
Singhnath & 92.58 & 100.0 & 94.86 & 95.81 \\
Marich begun S & 100.0 & 93.93 & 100.0 & 97.97 \\
Marich begum L & 100.0 & 77.45 & 100.0 & 92.48 \\
BAU Begun-1 & 100.0 & 100.0 & 100.0 & 100.0 \\
Ishurdi BS & 100.0 & 100.0 & 100.0 & 100.0 \\
Chega & 100.0 & 92.58 & 100.0 & 97.52 \\
Average & & & & 96.86 \\
\hline
\end{tabular}

The average value for intra-variety similarity indices $\left(\mathrm{S}_{\mathrm{i}}\right)$ was higher (average 96.86 ) than intervariety similarity indices $\left(\mathrm{S}_{\mathrm{ij}}\right)(88.13)$. The highest level of both intra- and inter-variety similarity indices were generated using the primer OPE8 (Table 5). The lowest intra-variety similarity indices $\left(\mathrm{S}_{\mathrm{i}}\right)$ and inter-variety similarity indices $\left(\mathrm{S}_{\mathrm{ij}}\right)$ were produced using primer OPB07.

Table 5. Band sharing based percentage similarity intra- and inter-variety indices generated using the primer.

\begin{tabular}{lcc}
\hline Primers & Intra-variety similarity indices $\left(\mathrm{S}_{\mathrm{j}}\right)$ & Inter-variety similarity indices $\left(\mathrm{S}_{\mathrm{i}}\right)$ \\
\hline OPA17 & 97.59 & 86.98 \\
OPB07 & 93.53 & 85.29 \\
OPE 8 & 99.48 & 92.04 \\
Average & 96.86 & 88.13 \\
\hline
\end{tabular}




\section{Genetic distance and genetic identity}

The values of pairwise comparisons for Nei's (1972) genetic distance between varieties/ genotypes were determined using the combined data for the 3 primers and ranged from 0.0513 0.3724 (Table 6). The genetic distance values between the ISD 006 and Dohazari G genotypes was found to be the highest (0.3724), and the lowest genetic distance (0.0513) was observed for the ISD 006 and Ishurdi $L$ genotype pair. A comparatively higher genetic distance was observed between the Laffa S vs Marich begun L (0.3605), Jessore L Vs Chega, and Marich begun L Vs Chega variety combinations. The genetic distance values indicated that the varieties were genetically different from each other. Stedje and Bukenya (2003) examined variation in Solanum and found no correlation between genetic distance and geographic distance. To obtain the maximum heterosis, genotypes with a greater genetic distance can be used as parents in crossing programs. Similar results have been reported by Latif et al. (2013), Rafii et al. (2012), and Shabanimofrad et al. (2013).

\begin{tabular}{|c|c|c|c|c|c|c|c|c|c|c|}
\hline Varieties & ISD 006 & Laffa S & Dohazari G & Jessore L & Singhnath & Marich begun S & Marich begun $\mathrm{L}$ & BAU Begun-1 & Ishurdi L & Chega \\
\hline ISD 006 & - & 0.8284 & 0.6891 & 0.7500 & 0.8203 & 0.8313 & 0.8444 & 0.8500 & 0.9500 & 0.8153 \\
\hline Laffa S & 0.1882 & - & 0.8217 & 0.7774 & 0.8494 & 0.8169 & 0.6835 & 0.7774 & 0.7774 & 0.8441 \\
\hline Dohazari G & 0.3724 & 0.1963 & - & 0.8449 & 0.8131 & 0.7806 & 0.8012 & 0.8449 & 0.7410 & 0.8579 \\
\hline Jessore L & 0.2877 & 0.2518 & 0.1685 & - & 0.9149 & 0.7807 & 0.8119 & 0.9000 & 0.8000 & 0.7649 \\
\hline Singhnath & 0.1981 & 0.1632 & 0.2069 & 0.0890 & - & 0.9123 & 0.7797 & 0.8715 & 0.8715 & 0.8360 \\
\hline Marich begun $\mathrm{S}$ & 0.1847 & 0.2022 & 0.2477 & 0.2475 & 0.0918 & - & 0.7919 & 0.8820 & 0.8820 & 0.9059 \\
\hline Marich begun $\mathrm{L}$ & 0.1691 & 0.3605 & 0.2217 & 0.2084 & 0.2488 & 0.2333 & - & 0.9147 & 0.8958 & 0.7757 \\
\hline BAU Begun-1 & 0.1625 & 0.2518 & 0.1685 & 0.1054 & 0.1375 & 0.1256 & 0.0892 & - & 0.9000 & 0.8657 \\
\hline Ishurdi L & 0.0513 & 0.2518 & 0.2997 & 0.2231 & 0.1375 & 0.1256 & 0.1100 & 0.1054 & - & 0.8657 \\
\hline Chega & 0.2042 & 0.1694 & 0.1532 & 0.2680 & 0.1792 & 0.0988 & 0.2540 & 0.1442 & 0.1442 & - \\
\hline
\end{tabular}

Genetic identity between varieties was observed for the 3 primers, ranging from 0.6891 to 0.9500 . A comparatively high genetic identity (0.9500) was found for the ISD 006 and Ishurdi $L$ variety pair and the lowest was observed between ISD 006 and Dohazari G (0.6891). The average genetic identity was 0.82 . Similar results were reported by Karihaloo and Gottlieb (1995) and (Chakraborty, 2006).

\section{Unweighted pair group method with arithmetic mean dendrogram}

An unweighted pair group method with arithmetic mean dendrogram based on Nei's (1972) genetic distance was constructed (Figure 4). The 10 eggplant varieties were grouped into 2 main clusters: ISD 006, Ishurdi L, Marich begun L, BAU Begun-1, Marich begun S, and Chega grouped into cluster 1, while Laffa S, Dohazari G, Jessore L, and Singhnath were in cluster 2 (Figure 4).

In cluster 1, ISD-006, Ishurdi L, Marich begun L, and BAU Begun-1 formed sub-cluster 1, while Marich begun $\mathrm{S}$ and Chega formed sub-cluster 2 . Among the varieties of sub-cluster 1, ISD 006 and Ishurdi L produced sub-sub cluster 1, while Marich begun L and BAU Begun-1 belonged to sub-sub cluster 2. Among the varieties of sub-sub cluster 1, ISD 006 was in 1 group, while Ishurdi $L$ was in another group. In sub-sub cluster 2, Marich begun $L$ was in 1 group while BAU Begun-1 was in another group.

In cluster 2, Laffa S was in sub-cluster 1 while Dohazari G, Jessore L, and Singhnath formed sub-cluster 2. Again among the varieties of sub-cluster 2, Dohazari $G$ was in sub-sub 
cluster 1 and Jessore $L$ and Singhnath belonged to sub-sub cluster 2 . Two varieties were sub-sub cluster 2; Jessore L was in 1 group and Singhnath was in another group.

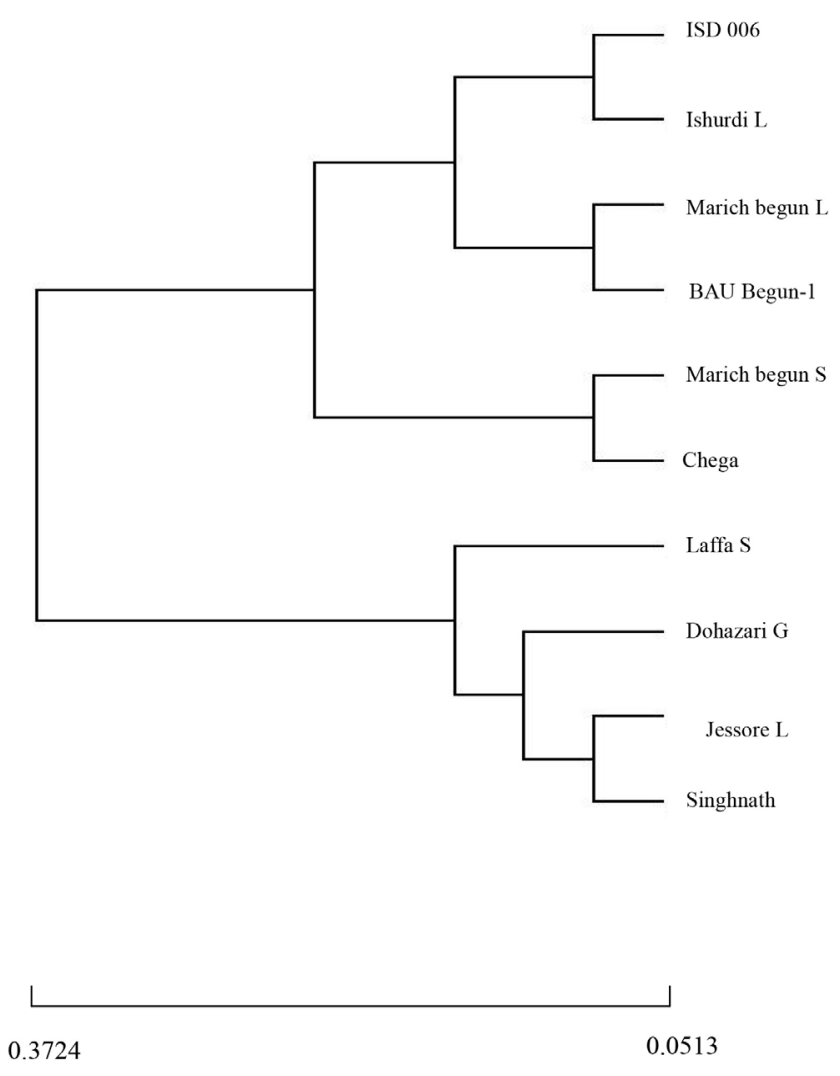

Figure 4. Unweighted pair group method with arithmetic mean dendrogram based on Nei's (1972) genetic distance summarizing the data on differentiation between 10 eggplant varieties, according to RAPD analysis.

Overall, BAU Begun-1, which is resistant to Phomopsis blight and Ishurdi L, Marich begun $S$, Marich begun $L$, and Chega were tolerant to phomopsis blight found in cluster 1. In contrast, Dohazari G, Laffa S, Singhnath, and Jessore $L$ were found to be in cluster 2, where all varieties were susceptible and moderately susceptible to Phomopsis blight, except Jessore L, which was moderately resistant/tolerant. This relationship of distinct groupings based on disease susceptibility was not reflected on the dendogram. This may have been because the RAPD primers were arbitrary and non-specific (not specific primers to Phomopsis blight) traits and adequate number of primers was not used. Additionally, their parental types may have been derived from the same origin. Similar results were found by Debasis et al. (2002) for potato late blight resistant and susceptible cultivars, for which there were no clear groupings based on the dendogram.

The results of the present study reveal the diversity among the eggplant varieties, which will be helpful for programs aimed at developing Phomopsis blight disease-resistant eggplant using biotechnological approaches and traditional breeding methods. 


\section{ACKNOWLEGMENTS}

The authors sincerely acknowledge the authorities of Bangaldesh Agricultural University, Mymensingh and Bangladesh Institute of Nuclear Agriculture, Mymensingh for financial support.

\section{REFERENCES}

Ali Z, Xu ZL, Zhang DY, He XL, et al. (2011). Molecular diversity analysis of eggplant (Solanum melongena) genetic resources. Genet. Mol. Res. 10: 1141-1155.

Aruga D, Tsuchiya N, Matsumura, H, Matsumoto E, et al. (2012). Analysis of RAPD and AFLP markers linked to resistance to Fusarium oxysporum f. sp. lactucae race 2 in lettuce (Lactuca sativa L.). Euphytica 187: 1-9.

BBS (Bangladesh Bureau of Statistics) (2011). Statistical Yearbook of Bangladesh. Bangladesh Bureau of Statistics. Ministry of Planning, Government of the Peoples' Republic of Bangladesh.

Chakraborty A (2006). Study of genetic variation and relatedness in different eggplant varieties using RAPD marker. MS thesis, Department of Biotechnology, Bangladesh Agricultural University, Mymensingh.

Choudhary B and Gaur K (2009). The development and regulation of Bt brinjal in India (Eggplant/Aubergine). International Service for the Acquisition of Agri-biotech Applications (ISAAA) Brief No. 38. ISAAA, Ithaca.

Das BH (1998). Studies of Phomopsis fruit rot of brinjal. Master's thesis, Department of Plant Pathology, Bangladesh Agricultural University, Mymensingh.

Demir K, Bakır M, Sarıkamış G and Acunalp S (2010). Genetic diversity of eggplant (Solanum melongena) germplasm from Turkey assessed by SSR and RAPD markers. Genet. Mol. Res. 9: 1568-1576.

FRG (2005). Fertilizer Recommendation Guide, Bangladesh Agricultural Research Council, Farmgate, Dhaka.

Islam MR (2006). An integrated approach for management of Phomopsis blight and fruit rot of eggplant. Ph.D. thesis, Department of Plant Pathology, Bangladesh Agricultural University, Mymensingh.

Islam SK, Sitansu P and Pan S (1990). Efficacy of humidity and temperature on Phomopsis fruit rot of brinjal (Solanum melongena). Environ. Ecol. 8: 1309-1310.

Izadiyan M and Taghavi SM (2013). Host range variation and genetic diversity of Iranian isolates of Ralstonia solanacearum from potato and tomato with RAPD and (GTG)5-PCR. J. Plant Pathol. 95: 87-97.

Joshi BK, Panthee DR, Louws FJ, Yencho GC, et al. (2013). RAPD Markers linked to late blight resistance in tomato. Nepal J. Sci. Technol. 14: 1-14.

Kabir MM (2007). Molecular characterization of $\mathrm{F}_{3}$ offspring of eggplant crosses for resistant to phomopsis blight and fruit rot. Master's thesis, Department of Plant Pathology, Bangladesh Agricultural University, Mymensingh.

Kalda TS, Swarup V and Choudhury B (1977). Resistance to Phomopsis blight in eggplant. Veg. Sci. India 4: 90-101.

Karihaloo JL and Gottlieb LD (1995). Random amplified polymorphic variation in the eggplant, Solanum melongena L. (Solanaceae). Theor. Appl. Genet. 90: 767-770.

Khalil MI, Meah, MB and Islam MM (2013). Morphological and molecular characterization of eggplant lines for resistant to Phomopsis blight and fruit rot. Int. J. Agric. Res. Innov. Technol. 3: 42-53.

Khodke PS (1990). Host range and varietal resistance to stem blight (Phomopsis vexans) of brinjal. Indian Phytopathol. $43: 315$.

Laila R, Siddiqua MK, Khali I, Robin AHK, et al. (2012). Molecular characterization of Solanum melongena using RAPD marker for collar rot resistance. Int. Res. J. Appl. Life Sci. 1: 38-65.

Latif MA, Rahman MM, Ali ME, Ashkani S, et al. (2013). Inheritance studies of SSR and ISSR molecular markers and phylogenetic relationship of rice genotypes resistant to tungro virus. C. R. Biol. 336: 125-133.

Meah MB (2003). Development of an integrated approach for management of Phomopsis blight and fruit rot of eggplant in Bangladesh. Annual research report (2002-2003). Department of Plant Pathology, Bangladesh Agricultural University, Mymensingh, Bangladesh.

Meah MB and Islam MM (2005). Development of an integrated approach for management of Phomopsis blight and fruit rot of eggplant in Bangladesh. Annual research report (2004-2005). Department of Plant Pathology, Bangladesh Agricultural University, Mymensingh, Bangladesh.

Meah MB, Das BH, Siddiqua MK and Nasir M (1998). Screening brinjal varieties and fungicides against Phomopsis rot. Bangladesh J. Bot. 19: 5-20.

Meah MB, Hossain MD and Islam MR (2002). Development of an integrated approach for management of Phomopsis blight and fruit rot of eggplant in Bangladesh. Annual research report (2001-2002). Department of Plant Pathology, Bangladesh Agricultural University, Mymensingh, Bangladesh.

Meah MB, Ahmed SA, Islam MR, Islam MM, et al. (2007). Eggplant of Bangladesh. 2nd edn. IPM Laboratory, Dept. of Plant 
Pathology, Bangladesh Agricultural University. Mymensingh.

Nei M (1972). Genetic distance between populations. American Nat. 106: 283-292.

Nei M (1973). Analysis of gene diversity in subdivided population. Proc. Nat. Acad. Sci. U. S. A. 70: 3321-3323.

Quaiser A and Ahmed Q (1987). Sources of resistance in brinjal to phomopsis fruit rot. Indian Phytopathol. 40: 98-99.

Rafii MY, Mahmoodreza S, Edaroyati PWB and Latif MA (2012). Analysis of the genetic diversity of physic nut, Jatropha curcas accession using RAPD-PCR molecular markers in Peninsular Malaysia. Mol. Biol. Rep. 39: 6505-6511.

Shabanimofrad M, Rafii MY, Megat Wahab PE, Biabani AR, et al. (2013) Phenotypic, genotypic and genetic divergence found in 48 newly collected Malaysian accessions of Jatropha curcas L. Ind. Crops Prod. 42: 543-551.

Sharmin D, Khalil MI, Begum SN and Meah MB (2011). Molecular characterization of eggplant crosses by using RAPD analysis. Int. J. Sust. Crop Prod. 6: 22-28.

Singh AK, Singh M, Singh R, Kumar S, et al. (2006). Genetic diversity within the genus Solanum (Solanaceae) as revealed by RAPD markers. Curr. Sci. 90: 357-364.

Singh RS (1984). An introduction to Principles of Plant Pathology. 2nd edn. IBH Publishing Company, Delhi.

Sobral BWS and Honeycutt RJ (1993). High output genetic mapping in polyploids using PCR generated markers. Theor. Appl. Genet. 86: 105-112.

Stedje B and Bukenya ZR (2003). RAPD variation in Solanum anguigi Lam. and S. aethiopicum L. (Solanaceae) in Uganda. Euphytica 131: 293-297.

Valdmar PC, Ruas F, Moreira MP and Paulo MR (2004). Genetic diversity among maize (Zea mays L.) landraces assessed by RAPD markers. Genet. Mol. Biol. 27: 2-4.

Williams JGK, Kubelik AR, Livak KJ, Rafalski JA et al. (1990). DNA polymorphisms amplified by arbitrary primers are useful as genetic markers. Nucleic Acids Res. 18: 6531-6535.

Yang X and Quiros CF (1995). Construction of a genetic linkage map in celery using DNA based markers. Genome 38: $36-44$.

Yasmin S, Islam MS, Nasiruddin KM and Alam MS (2006). Molecular characterization of potato germplasm by random amplified polymorphic DNA markers. Biotechnology 5: 27-31.

Yeh FC, Yang RC, Boyle TBJ, Ye ZH, et al. (1999). POPGENE. The user-friendly software for population genetics analysis. Molecular Biology and Biotechnology Centre, University of Alberta, Canada. 